Ekuitas: Jurnal Pendidikan Ekonomi

Volume 9, Number 1, Tahun 2021, pp. 18-26

P-ISSN : 2354-6107 E-ISSN : 2549-2292

DOI : $10.23887 /$ ekuitas.v9i1.32918

Open Access: https://ejournal.undiksha.ac.id/index.php/EKU

\title{
Local Agricultural Products Strategy to Improve Resilience in a New Adaptation Era
}

\author{
I Gusti Ayu Purnamawati ${ }^{*}$, Gede Adi Yuniarta², Elly Herliyani ${ }^{3}$ \\ 1,2,3Universitas Pendidikan Ganesha, Singaraja - Indonesia
}

\section{A R T I C LE I N F O}

Article history:

Received March, 62021

Received in revised form May, 122021

Accepted May, 252021

Available online June, 28 2021

Kata Kunci:

Adaptasi, ketahanan,

pertanian, produk lokal

strategi.

Keywords:

Adaptation, agricultural,

local product, resilience,

strategy.

\begin{abstract}
A B S T R A K
Ketahanan masyarakat dalam menghadapi pandemi Covid-19 membuat pemerintah mengucurkan dana untuk membantu perekonomian kembali tumbuh. Di tengah kepedulian masyarakat, sektor pertanian merupakan alternatif terpenting untuk bertahan hidup. Penelitian ini mencoba menganalisis strategi pengembangan produk lokal untuk bertahan dari keterpurukan di era adaptasi terhadap kebiasaan baru, khususnya usaha pertanian. Pendekatan yang digunakan adalah deskriptif kuantitatif. Subjek dalam penelitian ini adalah Dinas Perindustrian dan Perdagangan Provinsi Bali, pengelola agribisnis di Kabupaten Buleleng Provinsi Bali, dan konsumen yang membeli hasil pertanian tersebut. Strategi pengembangan menggunakan analisis SWOT. Pembobotan keempat variabel yang berpengaruh tersebut adalah strategi produk, strategi bersaing, kemitraan, dan teknologi dengan menggunakan pendekatan proses hierarki analitik. Penerapan strategi pertumbuhan dan stabilitas sektor pertanian melalui pemberdayaan masyarakat pedesaan mampu meningkatkan kebertahanan masyarakat.
\end{abstract}

\section{A B S T R A C T}

The resilience of the community in the face of the Covid-19 pandemic led the government to disburse funds to help the economy grow again. Amid public concern, the agricultural sector is the most important alternative to survive. This research tries to analyze local product development strategies to survive the downturn in the era of adaptation to new habits, especially agricultural businesses. The approach used is quantitative. The subjects in this study were the Bali Provincial Industry and Trade Office, agribusiness managers in Buleleng Regency, Bali Province, and consumers who buy these agricultural products. The development strategy uses SWOT analysis. The weighting of the four influential variables is the product strategy, competitive strategy, partnership, and technology using the analytical hierarchical process approach. The application of a strategy for growth and stability in the agricultural sector through the empowerment of rural communities can improve the resilience.

\footnotetext{
* Corresponding author.

E-mail : igapurnamawati@gmail.com (I Gusti Ayu Purnamawati)
} 


\section{Introduction}

The Covid-19 pandemic is a phenomenon that is being faced by people around the world, it even impacts all aspects of life. In recent periods, the world has experienced dramatic changes and weakened national economic growth. Several countries are undergoing significant structural changes, where traditional industries are being replaced by services and innovation sectors. This marks a transition to a knowledge economy with a variety of creativity (Čábelková et al., 2015; Żelazny \& Pietrucha, 2017). The agribusiness sector is also able to increase domestic production capacity and have an impact on employment. This sector also certainly has positive and negative impacts on a country's economic growth when viewed from an export and import perspective.

The performance of Indonesia's national development in general, and in particular the performance of development in the agricultural sector, is strongly influenced by the dynamics of the strategic environment, both from domestic change factors, as well as factors from abroad, or even external change factors. Human control (natural factors and global environment) known as external factors. These factors individually, or simultaneously will directly or indirectly affect the performance of the agricultural sector, which in turn will have an impact on the social and economic aspects of society. The government, in carrying out its duties, issues various regulations and policies as instruments to direct and encourage the growth of agricultural development, so that agricultural development can achieve development goals and targets set by the government. As a country that adheres to economic openness like Indonesia, economic development in general and especially the development of the agricultural sector cannot be separated from the influence of policy changes carried out by the state, or other groups of countries that have trade and economic relations with Indonesia.

Resilience includes the ability to be adaptive and transformative. Resilience offers alternative insights into agricultural management and balances short-term efficiency and long-term transformability, balancing exploitation between explorations. Agricultural resilience can be strengthened or eroded by policies and family dynamics. Overall resilience illustrates an alternative conceptual lens for building balance, thus highlighting complex dynamics and the role of institutions in driving change (Darnhofer, 2014). Research by Tian (2016) concerns companies that own most of the shares of government companies but get lower capacity utilization. The results of the study are in line with the development of the agribusiness industry in Bali Province which has an impact on the tight competition climate. Government policy alone is not enough to make the agribusiness industry able to compete, be independent, and contribute to the economy so that strategic steps are needed to develop it (Sulista, 2019). Morgan (2009), and also in line with VargasHernández \& Noruzi (2010), research finds that long-term development and empowerment carried out by the government plays a role in improving the sustainability of MSMEs competitiveness. Research by Hidayat \& Asmara (2017) states that the new economic resource is currently being encouraged by the Indonesian Government and is expected to help national economic growth. The results of this research, namely the business industry and innovation have a conceptual and practical relationship. Where both aim to support national economic growth. Research by Daubaraite \& Startienè (2015) about the influence of the trading industry on the national economy, especially the economic sub-sector. This research then became the basis for encouraging the growth and development of SME industries in the national economy.

The agribusiness industry is currently growing rapidly in various developed countries. However, the development was less connected between regions in a country, so that the development of this trading industry began to be supported by the government and academics (Maryunani \& Mirzanti, 2015). The trading economy is a relevant part of the development of modern industry because it has the potential to generate income and expand employment opportunities in other sectors (Kon, 2016). The combination of creativity and local culture makes Bali's agribusiness industry well-known both locally and internationally (Skavronska, 2017). Research by Sarijani et al (2015), show that in the culinary field, creativity and innovation play an important role in product diversification and creating new ideas. So that it contributes greatly to increased sales of turnover, customers, and profits. Research by Jiao et al (2017), the research analysis shows profit model innovation in animation projects can be divided into fans mode, popular mode, placement mode, and Failure mode, respectively.

The resilience of the community in the face of the Covid-19 pandemic led the government to disburse funds to help the economy grow again. Amid public concern, the agricultural sector is the most important alternative to survive. Labor factors have a direct influence on the production process (Travkina \& Tvaronavièiene, 2011). According to Squazzoni (2009), the research relates to the main role of community development companies (CDC) in the form of bottom-up local economic initiatives. Research by Firdaus et al (2018); Mensah et al (2013), to stimulate economic growth and development, local economic development involves the identification and use of local resources, ideas, and skills aimed at creating employment opportunities, reducing poverty, and redistributing resources and opportunities for the 
surrounding communities. Mokoena (2017), Heideman (2011), shows that municipal LED staff can act as facilitators to initiate and mobilize further company identification processes as supporting agents of state companies around the LED locus, without crossing the line between facilitation and project implementation. Rogerson \& Rogerson (2010), LEDs give special meaning to the tourism and economic sectors in Africa, especially in increasing the potential of local relations in terms of employment, sourcing and procurement, SME development, and outsourcing.

\section{Methods}

This study is descriptive-quantitative research. Subjects determination in this study used the purposive sampling technique. This study used a survey method. This study used a qualitative approach to obtain as much information as possible through observation and in-depth interviews. The Mix Method is used to strengthen the results of research that cannot be fully explained by statistical data. This study uses in-depth interviews to obtain research information through questions and answers when meeting face to face or without using interview guides, and focus group discussions (Bungin, 2010). The subjects in this study were the Bali Provincial Industry and Trade Office, agribusiness managers in Buleleng Regency, Bali Province, and consumers who buy these agricultural products. To generate the development strategy, SWOT strategy alternative analysis (Lukmandono, 2015).

This analysis aims at the sustainability of farmers and agribusiness entrepreneurs in supporting an independent, sovereign, and sustainable agricultural industry. This study will later be able to provide input and alternative formulations or policy recommendations to policymakers to anticipate and overcome various problems in agricultural and rural development, both at the regional and national levels. The expected outputs from this study or research are alternative formulations or policy recommendations that include (1) information on the dynamics of agricultural development problems; and (2) information on the impact of the policy on resources, production, trade, and farmers' income on various agricultural commodities.

The potentials and problems obtained in the previous analysis were classified into components of strengths $(\mathrm{S})$, weakness $(\mathrm{W})$, opportunities $(0)$, and threat $(\mathrm{T})$, then alternative strategies were obtained by integrating internal components ( $\mathrm{S}$ and $\mathrm{W}$ ) and external components ( $\mathrm{W}$ and $\mathrm{T}$ ), to derive a combination of SW, SO, WT, and WO strategies. The competitive advantage of the trading industry must be continuously pursued, to increase the growth of the agribusiness industry more easily achieved. To support the strengthening of the competitiveness of the agribusiness industries, it is necessary to analyze competing strategies by evaluating the strengths, weaknesses, opportunities, and threats. The next step is to compile an IFAS matrix (internal strategic factor analysis summary), an EFAS matrix (external strategic factor analysis summary), and IE (internal-external) matrix. The result of this model is a strategy and action plan of competitiveness development to answer the purpose of research that is determining competitive strategic advantage in the agribusiness industry sector.

Table 1. SWOT Strategic Issues

\begin{tabular}{ccc}
\hline Internal External & Strengths (S) & Weakness (W) \\
\hline Threat (T) & Strategy ST & Strategy WT \\
& Use S to avoid T & Minimize W and avoid T \\
\hline Opportunities (0) & $\begin{array}{c}\text { Strategy SO } \\
\text { Use S to utilize 0 }\end{array}$ & $\begin{array}{c}\text { Strategy WO } \\
\text { Overcome W by utilizing O }\end{array}$
\end{tabular}

Source: Lukmandono (2015)

\section{Results and Discussion}

The Government of Buleleng Regency has carried out various policies and programs aimed at increasing production and productivity of the agricultural sector, as well as improving the welfare of farmers and rural communities in general, as well as especially for strait villages which have great potential in the development of the agricultural and agro-tourism industry. To respond to socio-economic dynamics and their impacts, a strategy is needed regarding the development of a sales system based on agribusiness technology that can provide opportunities for farming communities in particular and local governments to answer very fast market needs with the dynamism of the development of marketing technology in it to improve the economy, independence, and sustainable. The current situation of the Indonesian economy 
which is relying on Micro, Small, and Medium Enterprises (MSMEs) is one of the basic determination of government strategy in recovering the national economy that is the development focusing on the empowerment of MSMEs. The important role of MSMEs as business people is shown through one of the indicators that are the amount numbers and activity in various business sectors and subject to the public interest. Besides being the largest business sector in its contribution to the national development, MSMEs is also providing the opportunity of considerable job vacancies for domestic workers, so that its role is very important in helping the government to reduce unemployment. LED is a partnership process between local governments, stakeholders, and the private sector in managing natural resources and human resources and institutions that aim to encourage regional economic growth and create new jobs. Trade activities are one of the drivers of the country's economy and an important component in international trade because they can increase the marketing of agribusiness products in developing countries including Indonesia, and increase foreign exchange earnings. Mokoena (2017), the results of his research stated that LEDs have a positive effect on the country's economic growth if the environment in which SMME operates is profitable for MSMEs to achieve prosperity. So that the import trade balance is one of the macroeconomic indicators in a country. If the export value exceeds the value of imports, it can be said that the country is experiencing rapid development and simultaneously influencing development financing.

Trading industry business is only supported by the workforce and a collection of ideas, thus attracting larger companies. The main prerequisites in the agricultural industry are a collaboration among various actors who play the role of intellectuals, the business world, and the government. To obtain maximum results and the accuracy of this study, researchers used a triangulation test so that the results obtained from all business actors consisting of elements of companies, associations, and government can reflect the actual conditions. SWOT strategic issues that describe both internal and external conditions. The next step is to compile an IFAS matrix which is a detailed description and quantitatively of the strengths and weakness variables. For weakness, its scoring is the opposite of strength. While to distinguish the value of weight between range $0-1$ (weight total $=1$ or 100 percent) for each variable based on importance or unimportance criteria give impact to strategic factor: weight value 0 show not important and weight value 1 indicate very important. For weighting sub items using a pro strategy (same comparison) between subitems. The weights for four influential variables are manufacturing strategy, competitive strategy, partnership, and technology used analytical hierarchy process approach which is one of the multi-criteria decision-making methods that plays role in formulating and analyzing a decision into hierarchy structure of objectives, criteria, and alternatives (Sharma et al., 2008). The result of the internal strength score is 3.05 and the internal weakness is 1.42 obtained by the average score for internal factor 2.24 .

The next is the EFAS matrix which is a detailed and quantitative description of the variable of opportunities and threats. For threats, scoring is the opposite of opportunities. The result of the external opportunity score of 3.24 and the external threat score of 1.32 totaled 4.56 so that the average score for the external factor can be from the total value divided by the two factors to obtain a value of 2.28 . The externalinternal matrix is arranged by IFAS and EFAS values. This matrix is a preliminary model for obtaining a competitive industrial development competitiveness strategy. IFAS values are between 2.00 until 3.00 , then in the position matrix is in the average position, and the EFAS value is also between 2.00 until 3.00 , then in the position matrix is in the middle position. Considering these meetings between the IFAS and EFAS scores directs the position of the manufacturing industry to implement the Growth and Stability strategy (Lukmandono, 2015). The result shows ten strategies proposed to improve the competitiveness of agribusiness industries. Ten proposed strategies have considered the factors of strength, weakness, opportunities, and threats that occur. The development action plan shows the proposed technical issues for agribusiness industry actors in all sectors (Figure 1).

a. SO Strategy

1) Improving the competitiveness of agribusiness industries through the utilization of land and fertilizers, human resources, and market potential: expanding the distribution range, promoting domestic, human resource training to improve production mastery.

2) Strengthening the partnership relationship between government and business actors: enhance intensive interaction between government, business institutions, and business actors, unify the common mindset between government and business actors to define the goals of developing agribusiness industries.

3) Establishment of technology base to support the development of agribusiness industry: develop technology incubators both in educational and private environments, mapping to determine the priority of agribusiness technology bases.

b. WO Strategy

1) Enhance competitive advantage through productivity: conducting structuring supporting industries through cultivation, relocation, and searching for alternative land and fertilizers, 
conducting coaching and training of agribusiness industries in the regions to obtain the distribution of agribusiness industries, improved transport, and communications infrastructure to facilitate the availability of alternative land and fertilizers.

2) Increased ability of human resources in utilizing alternative land and fertilizers: conducting the intensification of labor training in the processing of appropriate alternative land and fertilizers and environmentally friendly, working closely with high education for alternative land and fertilizers technology research.

c. ST Strategy

Strengthening a conducive business climate to support new technology investments: the socialization of information, communication, and technology regulation to the entire community in a sustainable manner providing technological investment incentives and technology infrastructure.

d. WT Strategy

Increased appreciation of quality local products: socialize the use of local products by building agribusiness industry marketing centers, using local content in each of our agribusiness products while keeping abreast of market trends.

Creation of schemes and financing institutions that support the development of agribusiness industries: developing a financing institution in a center of the agribusiness industry, prioritize financing assistance to SMEs based agribusiness, encourage the agribusiness industry financing schemes through banking credit, CSR.

Table 2. SWOT Map Agribusiness Industries

\begin{tabular}{|c|c|}
\hline \multicolumn{2}{|r|}{ Influential Factor: Production Strategy } \\
\hline Strength & $\begin{array}{l}\sqrt{ } \text { Distribution channels for more and more marketing } \\
\sqrt{ } \text { A portion of the agribusiness industry subsector is a trading industry }\end{array}$ \\
\hline Weakness & $\begin{array}{l}\sqrt{ } \text { The yield of some agribusiness industry sub-sector is less attractive } \\
\sqrt{ } \text { Low bargaining power to distributors }\end{array}$ \\
\hline Opportunities & $\begin{array}{l}\sqrt{ } \text { The opening of increasingly diverse marketing channels } \\
\sqrt{ } \text { The market potential is quite large }\end{array}$ \\
\hline Threat & $\begin{array}{l}\sqrt{\text { Domestic agribusiness actors have an opportunity to improve production strategy }} \\
\sqrt{ } \text { Some domestic industrial locations are difficult to reach } \\
\sqrt{ } \text { The strength of innovation of imported products } \\
\sqrt{ } \text { Strength of price and quality of imported products }\end{array}$ \\
\hline \multicolumn{2}{|r|}{ Influential Factor: Competitive Strategy } \\
\hline Strength & $\sqrt{ }$ Strategic and product differentiation is quite good \\
\hline Weakness & $\begin{array}{l}\sqrt{ } \text { Weak processing of availability of alternative land and fertilizers into valuable } \\
\text { products }\end{array}$ \\
\hline Opportunities & $\begin{array}{l}\sqrt{ } \text { The availability of abundant raw materials } \\
\sqrt{ } \text { The availability of sufficient human resources }\end{array}$ \\
\hline Threat & $\sqrt{ }$ Low-cost competitor products \\
\hline \multicolumn{2}{|r|}{ Influential Factor: Partnership } \\
\hline Strength & $\sqrt{ }$ Government support for agribusiness industry development is good enough \\
\hline Weakness & $\sqrt{ }$ Lack of financial institutions supporting the agribusiness industries \\
\hline Opportunities & $\begin{array}{l}\sqrt{ } \text { Strong commitment from the government to improve fund disbursement } \\
\sqrt{ } \text { Large industrial CSR for agribusiness industry funding }\end{array}$ \\
\hline Threat & $\sqrt{ }$ The decline of appreciation and culture of domestic tolerance \\
\hline \multicolumn{2}{|r|}{ Influential Factors: Technology } \\
\hline Strength & $\begin{array}{l}\sqrt{ } \text { The availability of a free software system to support the management system } \\
\sqrt{ } \text { The condition of information technology is getting better }\end{array}$ \\
\hline Weakness & $\sqrt{ }$ The weak ability of business actors in technology \& information systems \\
\hline Opportunities & $\sqrt{ }$ Technology improved by the telecommunications industry to support connectivity \\
\hline Threat & $\sqrt{ }$ The frequent use of technology illegally by business actors \\
\hline
\end{tabular}




\section{INTERNAL FACTOR STRATEGY}

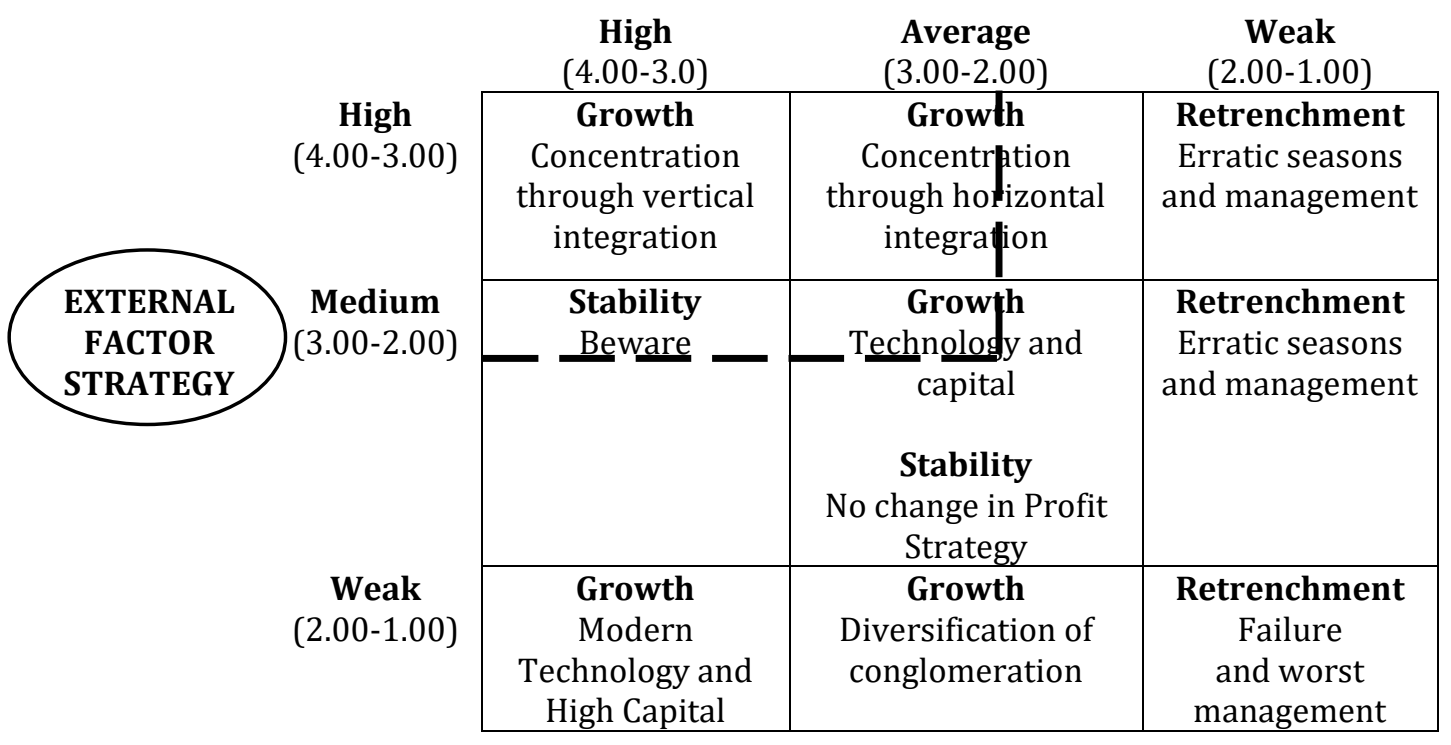

Figure 1. External Agribusiness Industry and Internal Matrix

Factors affecting agribusiness are domestic factors and international market factors. One of the domestic factors is the amount of production, the production subsidy from the government is proven to stimulate the trading of a country (Girma et al., 2007). Based on data analysis: SO Strategy by improving the competitiveness of agribusiness industries through the alternative land and fertilizers, human resources and market potential: expanding the distribution range, promoting domestic promotion, human resource training to improve production mastery, strengthening the partnership relationship between government and business actors: enhance intensive interaction between government, business institutions, and business actors, unify the common mindset between government and business actors to define the goals of developing agribusiness industries. Establishment of technology base to support the development of agribusiness industry: develop technology incubators both in educational and private environments, mapping to determine the priority of agribusiness technology bases. According to Thompson et al (2019) research showed that farmers' perceptions of the benefits of applying precision agricultural technology were heterogeneous. So that in the decision to adopt farmers, they must know about the benefits provided by precision agricultural technology. Firdaus et al (2018) through SWOT Matrix; SO strategy, namely accessibility of adequate transportation facilities, modern hotels; ST strategies that are not expensive and are supported by security; WO Strategy, namely improving human resources, water facilities, and infrastructure and processing waste, improving facilities in rooms; The WT strategy is to avoid the transfer of educated and experienced personnel.

The condition of agribusiness development and regeneration is also strengthened by the age range of respondents in the age range between 20-29 years of 2 percent, age range of 30-39 years of 8 percent, age range of 40-49 years of 49 percent, age range> 50 of 41 percent (50-59 by 25 percent, 60-69 by 14 percent, $\geq 70$ by 3 percent) of the total respondents, as in Figure 2 .

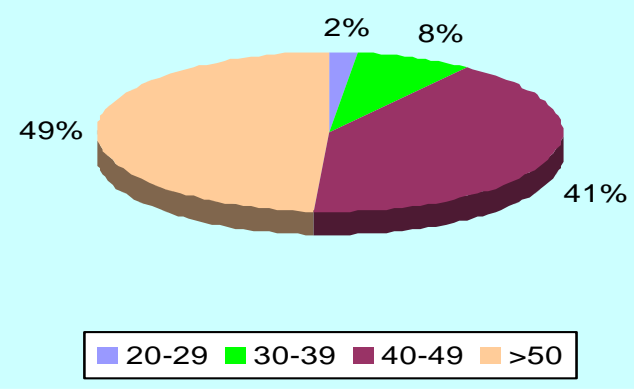


Figure 2. Age Distribution of Agribusiness Entrepreneurs

Based on Figure 2, it can be seen that currently agricultural agribusiness entrepreneurs are dominated in the 40-49 year age range. It takes special efforts from various parties to arouse the interest of the younger generation to engage in businesses in agriculture and agribusiness. In addition to joining the business community network to get new ideas that are useful, after the harvest process an extensive product marketing network is needed by taking advantage of business opportunities. With the existence of a marketing network to improve the distribution channels for marketing agricultural and plantation products, introducing/selling products becomes easier and the network and reach wider. Also, if this market access can be managed properly, it can increase consumer loyalty and marketing networks.

According to Alrubaiee and (Alrubaiee \& Al-Nazer, 2010), along with the environment that continues to develop and change rapidly, companies cannot maintain an attitude characterized by attracting customers or expanding new markets. The key success factors for survival in mature markets depend on the sustainability of long-term relationships with stakeholders According to the theory of Conservation of Resources, individuals seek to maintain and protect resources. The results indicate that the innovation made by entrepreneurs can also be realized through the role of entrepreneurial orientation in every activity to achieve company goals with the support of business networks. Business networks allow entrepreneurs to find new ideas that are useful in making innovative breakthroughs. Networking is becoming increasingly important because it makes it easier for companies to access information, resources, markets, and technology. Especially amid efforts to rise from the economic downturn due to the Covid-19 Pandemic, it is hoped that the role of the government in facilitating capital for entrepreneurs engaged in agriculture.

Several policies support related to sustainable agricultural development that needs to be considered are the elimination of constraints and distorting policies, in the development of sustainable farming; implementing regulations and incentive systems for actors and implementing sustainable agriculture, such as investment incentives, financial rewards, environmentally friendly agricultural certification systems; investment in technological innovation in the context of minimizing trade-offs between high economic growth and poverty alleviation in agricultural development (such as conservation technology and development of vegetable pesticides); and institutional capacity building and initiative programs of action related to agroforestry development, community participation-based watershed development to prevent land degradation and erosion.

The strategy of LED application in Bali Province through partnership forum has been proven in increasing the local capacity both ability of stakeholder's cooperation and optimization of local natural resources. However, it does not mean the process and practice of applying the concept of LED in Bali Province works optimally. The activities undertaken to gain a competitive advantage in the agribusiness industry in this research can be summarized as follows: improving the competitiveness of agribusiness industries through the alternative land and fertilizers, human resources and market potential, strengthening partnerships between government and business actors, the establishment of technology base to support the development of the agribusiness industry, to increase competitive advantage through efficiency and productivity, to increase efforts to create an asset, to increase the capability of human resources in alternative land and fertilizers, to increase government support, strengthening a conducive business climate to support new technology investments, enhanced appreciation of quality local cultures and products, creation of schemes and financing institutions that support the development of agribusiness industries.

The technological approach is considered to be the right approach and is expected to be able to overcome various weaknesses in the planning, development implementation, and development approaches that have caused agricultural development to decline. In this context, one of the agricultural development missions that must be fought for is to improve the welfare of farmers.

\section{Conclusions and Recommendations}

The factors of the community's potential which support the developing agribusiness industry such as capital, basic resources, supporting institutions, group factor for a specialist, investment factor, labor, competitiveness, and subsidies. For this reason, to increase the efficiency of agricultural development in the future, a sales system that is focused on products and areas is required to increase growth and achieve agricultural targets is required. Through this study, it is recommended that to improve food security, especially in rural areas, it is necessary to reorient government policies or programs with an emphasis on the development of the agricultural and rural sectors to be able to generate added value that can be enjoyed by farmers. Agricultural development and rural development, apart from increasing people's income, are also expected to be able to curb the rate of urbanization and reduce the number of poor people, as well as an effort to increase income distribution and strengthen national food security. 


\section{Acknowledgements}

We thank for the funding provided by Lembaga Penelitian dan Pengabdian Masyarakat Universitas Pendidikan Ganesha and related parties.

\section{References}

Alrubaiee, L., \& Al-Nazer, N. (2010). Investigate the Impact of Relationship Marketing Orientation on Customer Loyalty: The Customer's Perspective. International Journal of Marketing Studies, 2(1), 155174. https://doi.org/10.5539/ijms.v2n1p155

Bungin, B. (2010). Metodologi Penelitian Kuantitatif (Edisi Kedu). Jakarta: Prenada Media Group.

Čábelková, I., Strielkowski, W., \& Mirvald, M. (2015). Business influence on the mass media: a case study of 21 countries. Transformation in Business \& Economics, 14(1), 65-75.

Darnhofer, I. (2014). Resilience and Why it Matters for Farm Management. European Review of Agricultural Economics, 41(3), 461-484. https://doi.org/10.1093/erae/jbu012

Daubaraitè, U., \& Startienè, G. (2015). Creative Industries Impact on National Economy in Regard to Subsectors. Procedia - Social and Behavioral Sciences, 129-134.

Firdaus, T., Agustiani, I. N., \& Agastya, I. M. D. (2018). Promotional Strategy Analysis In Improving The Rooms In Zodiak Hotel Kebon Kawung. Trikonomika, 17(2), 65-71.

Girma, S., Kneller, R., \& Pisu, M. (2007). Do Exporters Have Anything to Learn From Foreign Multinationals. European Economic Review, 51(4), 981-998.

Heideman, L. (2011). Municipal Local Economic Development and the Multiplier effect: Piloting a Community Enterprise Identification Method in South Africa and Namibia. Commonwealth Journal of Local Governance, 8 \& 9, 85-111.

Hidayat, A. R. T., \& Asmara, A. Y. (2017). Creative Industry in Supporting Economy Growth in Indonesia: Perspective of Regional Innovation System. IOP Conference Series: Earth and Environmental Science, $1-10$.

Jiao, H., Wang, Y., Xiao, H., Zhou, J., \& Zeng, W. (2017). Promoting Profit Model Innovation in Animation Project in Northeast Asia: Case Study on Chinese Cultural and Creative Industry. Sustainability, $9(2361), 1-17$.

Kon, A. (2016). on the creative economy chain in Brazil: potential and challenges. Brazilian Journal of Political Economy, 36(1), 168-189.

Lukmandono. (2015). Analisis SWOT Untuk Menentukan Keunggulan Strategi Bersaing Di Sektor Industri Kreatif. Seminar Nasional Sains Dan Teknologi Terapan III, 171-184.

Maryunani, S. R., \& Mirzanti, I. R. (2015). The Development of Entrepreneurship in Creative Industries with Reference to Bandung as a Creative City. Procedia - Social and Behavioral Sciences, 387-394.

Mensah, J. K., Domfeh, K. A., Ahenkan, A., \& Bawole, J. N. (2013). Policy and institutional perspectives on local economic development in Africa: The Ghanaian perspective. Journal of African Studies and Development, 5(7), 163-170.

Mokoena, S. K. (2017). The role of Local Economic Development (LED) : some empirical findings on the Small, Medium and Micro Enterprises (SMMEs). Journal of Public Administration, 52(2), 466-479.

Morgan, J. Q. (2009). The Role of Local Government in Economic Development Survey Findings from North Carolina.

Rogerson, C. M., \& Rogerson, J. M. (2010). Local economic development in Africa: Global context and research directions. Development Southern Africa, 27(4), 465-480.

Sarijani, E., Baedhowi, \& Sawiji, H. (2015). Peran Kreativitas Dan Inovasi Pelaku Usaha Dalam Diversifikasi Produk Kuliner Pada Kedai Steak \& Chicken Di Kab. Magetan Tahun 2014 (Implementasi Pendidikan Kewirausahaan).

Sharma, M. J., Moon, I., \& Bae, H. (2008). Analytic hierarchy process to assess and optimize distribution network. Applied Mathematics and Computation, 202, 256-265. https://doi.org/10.1016/j.amc.2008.02.008

Skavronska, I. V. (2017). Creative Industries In Ukraine: Analysis And Prospects Of The Development. Economics and Sociology, 10(2), 87-106.

Squazzoni, F. (2009). Local economic development initiatives from the bottom-up: the role of community development corporations. Community Development Journal, 44(4), 500-514.

Sulista. (2019). Keterkaitan Lapangan Pekerjaan Pertanian dan Pertambangan serta Pengaruhnya terhadap Persentase Tingkat Pengangguran Terbuka di Provinsi Kepulauan Bangka Belitung. Kajian Ekonomi \& Keuangan, 3(1), 76-86. https://doi.org/10.31685/kek.v3i1.440 
Thompson, N. M., Bir, C., Widmar, D. A., \& Mintert, J. R. (2019). Farmer Perceptions Of Precision Agriculture Technology Benefits. Journal of Agricultural and Applied Economics, 51(1), 142-163. https://doi.org/10.1017/aae.2018.27

Tian, X.-L. (2016). Participation in export and Chinese firms' capacity utilization. The Journal of International Trade \& Economic Development, 25(5), 757-784.

Travkina, I., \& Tvaronavièiene, M. (2011). Export Competitiveness and Domestic Productivity Facets: Case of Lithuania. JJournal of Business Economics and Management, 12(1), 49-68.

Vargas-Hernández, J. G., \& Noruzi, M. R. (2010). Study on Entrepreneurship and Role of Government in Enhancing Entrepreneurship by Establishing Small and Medium Enterprises, SMEs and Start-Ups.

Żelazny, R., \& Pietrucha, J. (2017). Measuring innovation and institution: the creative economy index. Equilibrium. Quarterly Journal Of Economics And Economic Policy, 12(1), 43-62. 